\title{
Fantasies of Refused Identities
}

\author{
Julia Creet
}

\begin{abstract}
Fantasmes d'identités refusées
A partir d'extraits de deux manuscrits autobiographiques de sa mère, Magda, Julia Creet explore ici les aspects fantasmatiques de la constitution de l'identité. Entre le reniement de la judä̈té et de ses traumatismes historiques chez Magda et l'affirmation politique d'une identitélesbienne chez Julia, entre le silence de la mère et la parole de la fille, il n'y a qu'un déplacement de fantasmes - un mouvement créateur de fictions identitaires.

Comment être témoin du passé de Magda sans combler les vides de son récit autobiographique, sans trahir son silence salutaire? "Respecter le silence fondamental de M[Magda] ne signifie pas que je ne peux pas écrire à propos de son passé, mais plutôt que je ne peux pas revendiquer son histoire au-delà de la portée qu'elle a eue dans ma propre existence.»
\end{abstract}

"The past" wrote M, (an initial my mother used for herself, Magda, and kept for her thinly veiled Maggie) "is like a missing tooth in the back of one's mouth." She never forgave the "barbaric" British dentists who pulled her molars instead of filling them, nevertheless her analogy continues, "it was painful while the tooth had hurt, hated to lose it, but now you know that it had to happen, that it doesn't really show, you don't mind it any more" ("New Canadians" 23). She meditates on whether forgetting the past is the act of a traitor or an act of survival - "If you have the desire to live, then you must learn to forget" - or if, in the final analysis, the decision to forget might simply have been out of her hands: "It seemed like Michael's decision at the time, I had just decided to roll along in my customary manner, but I suspect now that the decision was somewhere all around us" (24).

Michael knows my past. He does not know all the details, but he knows the outlines well enough. The funny thing is that I no longer remember when I had told him. It was before we were married, but 
I can't remember the night. It must have been at night, I could not have told him in the daylight - or perhaps I did. I seem to remember that I brazened it out, that I had talked about it in an emotionless way, pretending that it was all commonplace, and it didn't hurt any more. Where did he find the wisdom, where did he find the knowledge, to advise me not to talk about it any more? Not to talk about my past any more. How did he know that the cure lay in silence, in oblivion, not in dissection, not in eternal remembering. (23)

Memory and forgetting give rise to this extraordinary passage: the only direct reference to a four- or five-year gap between the end of $\mathrm{M}^{\prime}$ 's first manuscript, "A Path Through Puberty," and the beginning of her second, "The New Canadians." The "it" that she has decided to forget, the absent tooth, the silence all around her, is never fully disclosed, or perhaps even fully remembered. Nor is "it" ever fully forgotten. The analogy of the missing tooth is a fantasy of negation; it belies its conscious intentions by its physical and psychic associations. $M$ was exceptionally critical of physical imperfections, her own and others; covering her mouth when she laughed she tried to hide the gaps of her missing teeth. She taught my sister as a child to fear the symbolic associations of lost teeth: "Mum told me that to dream of losing a tooth was to predict a death in the family." Decaying teeth were a sign of dying, lost teeth a sign of the already or soon to be dead. Both manuscripts were acts of memory, written long after the events. Lacking the central story of loss, neither were ever published.

M gave me "A Path Through Puberty," when I turned twenty - "You areold enough to read it now" shesaid, but neverwhat "it" was. Iread it as the story of her childhood and coming of age. But the ending was wrong. She married a man that was not my father, and bore a child that was not a sibling I knew. It was autobiographical but fictionalized and, for some reason, I never asked which parts might be true. Or, perhaps, I never heard the answers. I may, as Nadine Fresco writes in "Remembering the Unknown," have refused to understand. "One might ask the same question a thousand times, one would forget a thousand times an answer with which one can do nothing. One pretends to pursue unrelentingly the reason for one's parent's silence, while, on the contrary, everything shows how much one avoids tearing away the veil from the forbidden" (421). I must have understood that the factual accuracy of M's "path" 
was of little consequence; I know now that she concealed more than she told. I have since used her silences to tell stories that are not necessarily hers; " $\mathrm{M}$ " was a real person and is now a usefulfiction.

Not unlike M's "it" is the phrase that echoes through Claude Lanzmann's Shoah: "And let's not talk about that." "[S]uch pleas/ commands," as David Carroll has argued,

are an admission that in certain circumstances not talking about "that" can be a powerful way of talking about it, that silence can at times say more and speak louder than discourse. They also acknowledge that discourse, if it is to say something about "that," must respect and maintain within itself a fundamental silence. (Heidegger vii)

M took, one might say, an oath of silence. "Not to talk about my past any more." Silence may be a defeat and a place of bondage, but it is also a sanctuary. As Dori Laub writes, "Silence is for them a fated exile, yet it is also a home, a destination, and a binding oath" (58).

"One of our discoveries," write four analysts studying Hungarian survivors and their descendants, "was that there is a universal tendency toward nearly total concealment of the Jewishness of the family and the ordeals they underwent..." (Szilágyi, Holocaust in Hungary 238). They attempt to distinguish between two types of concealment, the concealment of trauma and that of identity. Though parents suffer from the Holocaust as a trauma that "objectively cannot be verbalized," their descendants are "threatened by a new trauma," the concealment of being a Jew (248). This "new trauma" is the function of secrecy itself. What is concealed is inevitably wrong. "The secret of the Holocaust is," they point out, "thus connected to the secret of being a Jew." Yet, the intimacy of these two secrets seems impossible to separate. For Jewish identity itself has become so permeated by the trauma of the Holocaust that the identity has become a vehicle for trauma. For survivors, the ability to change identity was a mechanism of self-protection: "in the world such as that in which the survivors lived, identity becomes something like a garment that one can change at will" (Oliner, Generations 279).

When identity is indelibly marked by trauma, any identity becomes precarious. One might argue that any identity had associations of death for $\mathrm{M}$. The initial " $\mathrm{M}$ " - constant throughout her maiden (Magda), married (Mrs. M. Creet) and fictional names (Maggie) and attached to the front of my name, since, in the name of the mother, I was named 
Magdalene - seems to have had rhythmic and alliterative resonance for the writer who at one point proliferates her identities based on this initial:

Trust your instincts Maggie. Trust your life. Weare in Canada now; another chapter in the life of Maggie the Magyar, Maggie the magpie. (No, not that, never a thief. A cheat, yes too often, but not a thief.) All right then, let's try some more; Maggie the mad, Maggie the maddening, Maggie the martyr, Maggie the mysterious, Maggie the marvellous, and eventually, Maggie the maggot.

Oh, no. We are not thinking of death. We are never thinking of death. We did though, on the boat, coming over from England. ("The New Canadians" 14-15)

The "we" of this passage is perhaps the closest $\mathrm{M}$ comes to a jewish we, a we that thinks of death and its negation in the same thought. This is the voice of a diarist, first person, a voice of multiple modernist "Maggies," a collective we, and the voice of dislocation. Identities, like a garment that one can change at will, are in M's case also the cloak of death.

$M^{\prime}$ 's refusal of Jewish identity after the war, neither identifying herself as such, nor identifying with the fate of others, is also a defiant disavowal. Her refusal of identity began with her father before her. In 1903 Oszkár Groszman, a son of a poor shopkeeper, changed his name to György, a good common Hungarian name, one fitting to the young intellectual. Oszkár like many other European Jews wanted nothing more than assimilation. "I suspect that the decision [to forget] was somewhere all around us" she wrote, a statement that was true of her parents' generation also. To my sister, Minsisted that her father Oszkár was not Jewish, even though she saw him dismissed from his teaching post in 1937 and walked behind him in the death-march of 1944. Disavowal is a defence, a refusal to recognize the reality of a traumatic perception (Laplanche and Pontalis), elaborated by Freud as the fetishistic denial of the 'fact' of female castration, or with psychosis, the denial of reality itself. In its more general sense, however, M's refusal of Jewishness was a disavowal that was neither psychotic nor fetishistic, but in her own mind the only avenue of survival. She refused an imposed identification. Whether the identity was in any way 'real' or not, the results of its imposition were devastatingly real, and these two aspects of the trauma, identification and persecution, were indelibly linked.

In many political and therapeutic circles, $\mathrm{M}^{\prime}$ s silence cannot have any interpretation other than a pathological one. Yet, it was a legacy from her 
parents, one that a provided a dubious comfort. The attitude M's parents held towards the advancing war prefigured her post-war denials.

The war was raging all around but not yet in our country. My sister and I were kept in blissful ignorance, equalled only by our sexual ignorance. We were both well into our teens, but the preservation of our innocence from anything frightening or morbid was running on parallel lines with the importance of shielding us from anything vulgar or sordid....Unrealistic though it all was, I bless them for it, and I think they were right, because later on when the horrors did reach us, we were able to withdraw into our beautiful childhood, into our fearless past, and live in it temporarily, knowing that it was beyond anybody's power to touch or alter.... Was our parents' fear for our safety doubled because of their conspiracy to keep threats to it hidden from us? They were too intelligent and well informed to entertain hopes that the war was going to bypass us, but I think they must have decided to use the remaining years of peace to the very best advantage. ("Puberty" 53-54)

$\mathrm{M}$ honoured her parents' protection by writing of that childhood and almost never of the war. Yet, on another front, her reminiscences belie her parent's protection and contradict the aura of innocence and romanticism that was so blessedly preserved.

The dominant theme in M's manuscripts is sex. The tone is confessional; that of confidences whispered in secrecy. The confessions of " $A$ Path Through Puberty" are copious, sex with trusted suitors, wellmannered young men taken into the bosom of the family are frequent lovers. $M$ confesses to sexual encounters, frequent and unusual, not spoken about, not named, but enacted under her parent's noses within the realm of innocence. Eva was a border in M's house and a schoolmate; Eva was fifteen, $M$ fourteen. Complete indifference during the day contrasted passionate nights. M wrote of Eva:

She looked so warm and cosy, and I was so cold standing there by her bed, that she asked me to join her... a second-hand knowledge of sex out of books just didn't exist, and the idea that there could be sex or sexual urges between girls was unsuspected. The strange, warm delight I experienced in the vicinity of Eva took me by surprise...I found some quite unanticipated joy in her bed....I am certain that it all happened without words. Words of any sort, the asking of 
permission, or of endearment would have been an admission that we were aware of what we were doing; we were not, of that I am certain. Like young animals we were playing with each other, full of joy and innocence.... Her heavy warm burden on top of me, wriggling to and fro, getting frantic in her joy must have warned me that this was not permitted. We never mentioned it in daytime, and we never planned the nights which were to bring us together, and to my annoyance I don't know how or why we stopped.

With whom is she sharing her secrets now? To whom does she confess? It is to her father, Oszkár, I believe, who in the end failed to protect her innocence about either sex or death. The end of innocence comes at the end of "A Path Through Puberty." War and sex combine to force speech, acknowledgement and the enforcement of familial authority. I believe that much of M's account of her sexuality, her confessions, function as a trope for the loss of her family, for her inability to talk about "it."

Oszkár to Magda, a father who tried to assimilate, a daughter who tried to forget, to me, a granddaughter that proclaimed she was something else entirely, a body with a very different priority. I have begun to argue, or to try to figure out how one might argue, that identities can be unconscious displacements as much as they can also be conscious affirmations. On a hunch I say that my political emphasis on sexual identity, my intellectual and emotional obsession with lesbian identity, beyond having anything to do with finding girls, was/is an displacement from one physical marking, location, history to another. But what seems more important than the specifics of my new identifications (since each of my siblings has a different set) ${ }^{1}$ is to invoke a broader cultural picture of three generations of identity contortions.

How do I understand M's past? A (silent) narrative of trauma operative in my own life? Even after a few facts inadvertently slipped into our family circle, we never could talk to her about "it." What would we have said? $\mathrm{M}$ has been dead almost a decade now, her readers have become the vehicles of memory, "witnesses" in Shoshana Felman's terms. How to witness M? By her words - but also by my obsession with this thing called identity. Her abandonment of history and identity became my search, displaced from a history of a race to a history of an imaginary sexual tribe. The words of Elsa Brauer, Monique Wittig's legendary guérillère have taken on a haunting tone, "Make an effort to remember. Or, failing that, invent" (89). 
So much of identity and its ensuing politics are based on historical trauma. To claim Jewish identity or a history of persecution (and could I claim Jewish identity as anything other than a history of persecution?) makes little sense to me; both operate as imaginary narratives. But I am not about to reinvent Jewishness. For the invention of a new identity may have been my saving grace. Differentiation from the traumatic past of one's parents is often only possible after one establishes, as a means of individuation, a new identity, a new location in the world (Generations 308-309). Yet my draw to lesbianism was as much about a draw to an identity in crisis, as it was to a sensuality. For sexual political identities are also based on trauma, making visible contemporary and historical oppression. In fact, I acquired an identity for my sexuality before I had even performed it. In precisely opposite fashion from $\mathrm{M}$, at fourteen, in broad daylight I categorized an erotic feeling before ever having experienced its pleasures at night.

Remembering (or inventing) identities are good revolutionary practice, but what of forgetting (or refusing) them? Both are fantasies: invention is a productive political fantasy while negation is a disavowal and a form of survival. My displacement of M's abandonment of racial identity into my own search for sexual identity is also the transformation of a negating fantasy into a producing fantasy, quite similar to the tropological displacements at work in her fiction. My differentiation is also her displacement.

"Be whatever you want to be," hissed $\mathrm{M}$ in one of our many fights about my sexuality, "but for God's sake, keep your mouth shut about it." I understand her better now. What I was wasn't important, what struck fear and loathing in her, was my public performance of "it."

To respect M's fundamental silence does not mean that I cannot write of her "past," or that of her parents', but rather, that I cannot lay claim to that history beyond the extent to which it surfaced in my own life. Her history is not available to me; her experience not mine to deploy. What I am refusing is Jewish identity as the containment of trauma in favour of (re)producing my own - but then I have that luxury.

1 I have not addressed the differences between myself, my sister and my two brothers with respect to our mother's history. We are very different people and have reacted variously. We all do however, have two common questions which have been at the centre of deeply felt battles: 1 . What relationship do we have to a Jewishness - which is indelibly linked with trauma? and 2. Should we even be talking and writing about it? (But being a vocal and textual family, we do.) 


\section{Works Cited}

Bergmann, Martin S., Milton E. Jucovy, Eds. Generations of the Holocaust. (1982) New York: Columbia University Press, 1990.

Braham, Randolph, Ed. Studies on the Holocaust in Hungary. Columbia University Press, 1990.

Creet, Magda. "A Path Through Puberty." Unpublished manuscript. (1968?)

_. "The New Canadians." Unpublished manuscript. (1974?)

Felman, Shoshana and Dori Laub. Testimony: Crises of Witnessing in Literature, Psychoanalysis, and History. New York: Routledge, 1992.

Fresco, Nadine. "Remembering the Unknown." International Review of Psycho-Analysis 11 (1984): 417-427.

Laplanche, J. and J.-B. Pontalis. The Language of Psycho-Analysis. Trans. Donald Nicholson Smith. New York: Norton, 1973.

Lyotard, Jean-François. Heidegger and "the jews". (1988) Trans. Andreas Michel and Mark Roberts. Intro. David Carroll. Minneapolis: U of Minnesota Press, 1990.

Wittig, Monique. Les Guérillères. Trans. David Le Vay. New York: Avon Books, 1971. 